\title{
ECONOMY OF THE KAINGANG GROUP OF OESTE PAULISTA IN THE TERRA INDÍGENA VANUIIRE
}

\author{
ECONOMIA DO GRUPO KAINGANG DO OESTE PAULISTA NA TERRA INDÍGENA VANUÍRE \\ ECONOMÍA DEL GRUPO KAINGANG DE PAULISTA OCCIDENTAL EN TIERRAS INDÍGENAS DE VANUINA
}

\author{
Francisco Gilson Rebouças Porto Júnior \\ $\mathrm{PhD}$ in Communication and Contemporary Culture by \\ the Faculty of Communication of the Federal University \\ of Bahia. Professor at the Federal University of \\ Tocantins Foundation (UFT) and the Graduate Program \\ in Intellectual Property and Technology Transfer for \\ Innovation \\ gilsonportouft@gmail.com. \\ 0000-0002-5335-6428
}

\section{Valquiria Cristina Martins}

Master's student in Agribusiness and Development at UNESP / Campus de Tupã. Member of the PGEA group. Museum Educator. valcrismar@gmail.com.

0000-0002-8445-4207

\section{Nelson Russo de Moraes}

Professor of the Graduate Program in Agribusiness and Development at UNESP / Campus Tupã. Doctor in Communication and Contemporary Culture, from the Federal University of Bahia. Leader of the Democracy and Social Management Study Group. nelsonrusso.unesp@gmail.com.

\section{0-0003-0159-9433}

\section{Cristiane T. B. Marchetti}

Master's student in Agribusiness and Development at the Faculty of Science and Engineering / FCE / Tupã UNESP.cris.bazilio@hotmail.com.

0000-0002-7833-2975

\section{Anderson da C. Lacerda}

Graduate Program in Science, Technologies and Inclusion, Institute of Biology, Fluminense Federal

\author{
University, Niterói, \\ RJ, $\quad$ Brazil \\ costadelacerda@gmail.com. \\ 0000-0002-1862-2743
}

Mailing address: Federal University of Tocantins (UFT), Avenida NS-15, Quadra 109, Norte, s / n - Plano Norte, 77001-090 - Palmas, TO - Brazil.

Received: 10.12.2020.

Accepted: 11.20.2020.

Published: 01.01.2021.

\begin{abstract}
:
This article aims to describe the historical and ethnographic content of the Kaingang group from Oeste Paulista, in the Indigenous Land Vanuíre, and how they promote their economy. The Kaingang are peoples belonging to the Macro-Jê linguistic group, and the Jê family is considered one of the largest indigenous groups from the population point of view. The methodology adopted for the development of this article is based on bibliographic and descriptive typology, using documentary research as a technique. It is hoped to obtain, with this article, a systematic set of information, which, when reaching the objective of the work, can contribute to a better understanding of the economy of the Kaingang group in Western São Paulo, in the Indigenous Land Vanuíre.
\end{abstract}

KEYWORDS: Ethnodevelopment; Kaingang; Terra Indígena Vanuíre.

\section{Introduction}

One of the indigenous groups with the largest population in the Brazilian territory is the Kaingang, with approximately 34 thousand indigenous people, which corresponds to almost $50 \%$ of the entire Jê-speaking population. They are among the five most populous indigenous peoples in Brazil (ANDRIOLLI; CANDIDO, 2020).

The cultural historical path of this group has undergone several modifications, incited, mainly by the advance and pressures of our capitalist society, these, very little tried to understand the indigenous culture, in its objective there is no cultural strengthening and ancient permanence of local customs, to eating habits and to make a 
contribution, with a better quality of life, to those who were in these lands, before the arrival of the pioneers. It was not the focus of these, that the indigenous peoples could develop the most varied activities to strengthen their economy.

The Kaingang, in their traditional economy, cultivate agriculture, among which we can mention some: manioc, buggy / purple corn, some medicinal herbs, fruit trees. Also fishing, making different adornments (D'ANGELIS; VEIGA, 2009).

It is noticed that only some Indigenous lands with fertile soil for planting, other regions when sown, can occur: droughts, floods, frosts, situations which can compromise the indigenous economy according to Baptista (2008). It is added that there are few times that there is a river that passes through their lands where they can carry out traditional fishing with covo, or local fishing.

The present article has as general objective to understand, a historical and ethnographic bibliographic research, in how the Kaingang group of the West Paulista in the Indigenous Land Vanuíre promotes its economy.

As a specific objective, it is intended to characterize the culture of the Kaingang group from Oeste Paulista, in the Vanuíre Indigenous Territory, facing their economy; Understand the historical and ethnographic content of the Kaingang group from Oeste Paulista, in the Indigenous Land Vanuíre, and how they promote their economy; Identify the economy of the Kaingang group in Western São Paulo in the Indigenous Land Vanuíre.

For this purpose, as a methodology, as a way to achieve the proposed objective, this article will be developed by a descriptive analytical structure of actions as described below.

In-depth bibliographic survey of online databases, searching for scientific academic articles and classic books as well as sites related to indigenous issues such as the National Indian Foundation (FUNAI), India Vanuíre Historical and Educational Museum (MHPIV), Instituto Socioambiental (ISA), Museum do Índio, documentary searches in other Governmental and Non-Governmental Bodies, and for the research of this article the main keywords will be used: Kaingang, ethnodevelopment, agriculture, indigenous economy, ethnocognition, among others that may be necessary.

\section{The Kaingang of west paulista in the terra indígena Vanuine}

A continental country, Brazil, with an environmental, cultural and social biodiversity, establishes itself as the rule and not the exception in socialization and coexistence between individuals from its different regions. With far-reaching territorial extensions rich in its fauna and flora, and in its cultural aspects, underpinning the traditionalism of a good part of its population, especially in the interior (MORAES et al., 2016). 


\section{Obevisto}

The Kaingang Group, according to ISA (2020), was inserted at the end of the 19th century by Telêmaco Borba, initially, the Kaingang and the Xokleng were classified as a single indigenous community, even with different dialects. However, with the historical separation, each ethnic group developed its socio-cultural method, making them distinct.

Historically, the Kaingang do not differ from other indigenous peoples, with acts of violence practiced by society, these are several records accounted for by years of massacre and ethnocide due to capitalism. Pinheiro (1999) explains that in the 20th century:

The first half of this century, mainly the 30 s and 40 s, as analyzed in the speech of the constituents of 1933 and 1934, by Zélia Lopes da Silva and by the historians Silvia HZ Martins and Janete Leiko Tanno4 present several strategies used by the dominant class to control the population poor and to reorder it under rationalizing rules and plans. (PINHEIRO, 1999, p. 15).

The most varied attempts to control the indigenous population include the territoriality of the Kaingang community, leaving major consequences.

According to Silva and Laroque (2012):

Traditionally, the Kaingang Indians occupied an immense area of Southern Brazil, this comprised from the Southeast region to the extreme south of Brazil, thus forming "The Great Kaingang Territory". The limits of this occupation ranged from the Tietê River, in the southeast, through the States of Paraná, Santa Catarina and Rio Grande do Sul, the territory extended to the Jacuí and lbicuí Rivers. To the West, the Kaingang occupation advanced to the Argentine province of Misiones. (SILVA; LAROQUE, 2012, p. 436).

Logo Bussoli (2018) concludes that:

Expelled from their traditional territories from the middle of the 18th century and during the 19th century, the Kaingang never stopped circulating through their traditional territories and, especially from the second half of the 20th century in Rio Grande do Sul, started to undertake a process to retake their lands. (BUSSOLI, 2018, p. 12-13).

According to ISA (2020), the Kaingang are from the Marco-Jê linguistic branch, belonging to the Jê family and "[...] arrived in the south and southeast of Brazil 3,000 years ago [...]". Thus, in the history of this group we can highlight, as one of the starting points, this moment, having one of its historical records, in the West of São Paulo. (MHPIV, 2020, p. 01).

In the 17th century the Kaingang was registered: 
[...] in the upper course of the Uruguay River and in the 18th century they occupied the extensive forests of upper Uruguay, in an area that runs from the Piratini River (extreme West) to the Caí River Basin, to the east. Kaingang territories constituted the West of São Paulo, lands of the second and third plateaus of Paraná and Santa Catarina and the entire strip above the basins of the Piratini, Jacuí and Caí Rivers in Rio Grande do Sul (ISA, 2020, p. 01).

Gonçalves (2007) adds that:

The Kaingang are now considered one of the five most populous indigenous peoples in Brazil, with approximately 30 thousand people distributed in about 30 different indigenous areas between the states of São Paulo, Paraná, Santa Catarina and Rio Grande do Sul. (GONÇALVES, 2007, p. 02).

The Kaingang, in Alta Paulista, occupied the highest lands of the cerrado known as spikes, bordering the Tietê, Peixe, Aguapeí Rivers known as Feio and Paranapanema where the municipality of Tupã is located (MELATTI, 1976; PINHEIRO, 1992; MHPIV, 2020).

Pinheiro (1999) provides more details about the Kaingang group in western São Paulo:

The Vanuíre Village distant from the city of Tupã $23 \mathrm{~km}$, towards the airport. It covers an area of 604 hectares (ha). Bathed by Pirã, Koiós and lakri streams. The indigenous area is crossed three times by the municipal Road, in different directions. (PINHEIRO, 1999, p. 11).

The colonization of the western region of the state of São Paulo took place from the beginning of the 20th century, previously, the entire area cut by the São Jose dos dourados, Tietê, Aguapeí / Feio, Rio do Peixe and Santo Anastácio rivers were considered the unknown hinterland inhabited by indigenous people (MONTEIRO, et al., 1984).

In the middle of the 19th century and the beginning of the 20th century, processes of recognition, colonization and occupation of this territory were under way, through exploratory expeditions, organized by scientific commissions and institutions, some of a religious nature, with the objective of catechizing the found indigenous peoples, among its goals was the expansion of the coffee economy and the construction of new communication routes, among them the railways (MONTEIRO, et al., 1984).

According to Ribeiro (1988, p. 93):

The expansion of the Atlantic Forest advanced along the eastern slopes of the Serra do Mar, following the course of Rivers that flow to the West, such as the Rio Grande, Tietê, Paranapanema, Ivaí and Iguaçu, were the great forests and northern Paraná that covered much of the state of São Paulo, south of Minas Gerais. 
The culture of coffee has the impetus for export crops, as an important economic activity in the country, for the time. (RIBEIRO, 1988). With such an advance, in 1905 the construction of the Northwest Railway of Brazil began. At this time, the conflict also started, which intensified between the Kaingang and non-indigenous people (VEIGA, 2006; MONTEIRO ET al., 1984).

The railroad at that time had the objective of narrowing the distance between cities and boosting the development of the coffee economy in the State of São Paulo, something that would not have been possible without the expansion of the railway (MONTEIRO, et al., 1984).

With the creation of the railroad that would link Santos to Corumbá, affecting the Kaingang Indigenous Lands, grileiros who acquired fertile land at low cost (RIBEIRO, 2009) appear in this context.

In this period, "[...] for the expansionist society, the land of São Paulo at that time was another important element of the economic production of goods for export [...]" (PINHEIRO, 1992, p. 39).

Because the municipality of Bauru makes a connection with other railways Socorabana and company Paulista, it was chosen as the starting point for the construction of the railway (MELATTI, 1976; RODRIGUES, 2016).

Therefore, with the expansion of coffee and railroads in Alta Paulista, the Kaingang, in addition to suffering from various interventions in their social dynamics and in the way of occupying their territorial space, were considered as an impediment to the model of economic growth in the city. region, by defending the territory in which they lived. The farmers, politicians, and bugreiros hired by farmers motivated by the expansion given to coffee growing, fought for the private ownership of the land (RODRIGUES, 2007; RIBEIRO, 2009).

The Kaingang "[...] started to have their territories invaded by the State government and by the colonizers who, in an articulated way, were building the railway towards the hinterland that was actually Kaingang territory [...]" (ISA, 2020, p. 01).

It is at this moment that the impasse between the Kaingang begins, who in turn to defend their territory that was being invaded by farmers, land grabbers, destroyed the railway under construction to frighten the employees of companies, these employees in the face of the impasse, hired bugreiros to pursue the murder, the Kaingang, through the use of weapons and / or contamination by diseases causing mass death (RIBEIRO, 2009; CURY, FABRRI, 2019). 
Bugreiros invaded the Kaingang Lands, "[...] devastating fields, burning shacks and killing men, women and children. Road workers, also heavily armed, were happy to shoot randomly, kill into the woods, and to shoot any Indian they saw [...]" (RIBEIRO, 1988, p. 142).

Contaminated smallpox clothing was delivered, indigenous women and children were also imprisoned to attract the attention of men, among other subtle and pioneering ways, such as offers of alcoholic beverages, the biggest massacres occurred between 1908 and 1910 according to Ribeiro (2009).

This impact was so great that the Federal Government created the Indian Protection Service (SPI) for indigenous "pacification":

Decree Law No. 8,072 of June 20,1910, the SPI aimed to be an organ of the Federal Government in charge of executing the indigenous policy. Its main purpose was to protect the Indians and, at the same time, ensure the implementation of a strategy of territorial occupation of the country. (FUNAl, 2020 d, p. 01).

The creation of the SPI changed the approach to the indigenous issue in the country already and in 1911 a camp was established in Ribeirão dos Patos, which is the base of SPI operations in the region during this period (FABBRI, CURY, 2019).

Although the creation of the Indian Protection Service (SPI) for "pacification" took place in 1911, there is a record that the first "pacification" occurred in 1912, northwest of São Paulo, since this region was populated by the Kaingang. This operation was first conducted by Lieutenant Manoel Rabelo, then, until stabilization, it was conducted by Luiz Bueno Horta Barbosa, a university professor who fought for indigenous causes according to Ribeiro (1988).

The MHPIV (2020) highlights that the work of "pacification" of the Kaingang started in 1912, being that:

the last Kaingang group "pacified" in 1915 - 1916 were relocated to the Icatu Indigenous Post, a location that was acquired by SPI the previous year, and in 1917, due to disagreements between the Kaingang groups, the Vanuíre Indigenous Post (MHPIV) is created, 2020, p. 01).

For this "pacification", among the various Kaingang indigenous mediators, the indigenous Vanuíre stood out, as an interpreter singing in the Kaingang language and going to meet non-indigenous people to talk, contributing decisively to "pacification" (RIBEIRO, 1988). 
Several Kaingang from the Tibagi basin and other interpreters who were part of the expedition were called in to help with contacts in "[...] 1912, beginning of the conquest. Horta Barboza records that half of the Kaingang from São Paulo died of an influenza epidemic shortly after the first contacts between 1912 and 1913 [...]" (ISA, 2020, p. 01).

As highlighted by Moraes et al. (2016), in this complex social positioning of struggles for the possession of territories, indigenous peoples came over the centuries, losing their geographical spaces and observing the dissolution of their cultural traits, in the face of the strength of the elements arising from society, in turn, based on individualism and consumption.

These actions are corroborated by Gonçalves (2007), who mentions that in the state of São Paulo, the Kaingang were reduced to two small groups in two very small areas, Gonçalves (2007) adds that:

In the 1940s, SPI's official policy took indigenous individuals and families of other ethnicities to their areas, which resulted in the language's near extinction in the State of São Paulo. [...] In the 1980s, the Kaingang language was already considered extinct in the state of São Paulo. (GONÇALVES, 2007, p. 02).

Today in West Paulista there are three Indigenous Lands:

Icatu Indigenous Territory, located in the municipality of Braúna, with 300.9625 hectares, and two Kaingang and Terena indigenous groups (FUNAI, 2020c).

The Araribá Indigenous Land, is located in the municipality of Avaí with 2000 hectares, and three Guarani indigenous groups, Guarani Nandeva and Terena (FUNAI, 2020b).

And the Terra Indígena Vanuíre, located in the municipality of Arco-Íris, with 709 hectares and two Kaingang and Krenak indigenous groups with its largest population (FUNAl, 2020a), however, in addition to these groups, the Terra Indígena Vanuíre also houses other indigenous peoples with smaller population, the Terena, Aticun, Pankarau, Fulniô and Guarani people (MHPIV, 2020).

Therefore, when analyzing an ethnic group as inferior, at this moment there will be an act of discrimination, prejudice. Dambros et al. (2020) realized these characteristics, by adding that:

In Brazilian society there is still prejudice, discrimination and exclusion of indigenous people; it is necessary to advance in respect for the rights of these people and to strengthen their own institutions, cultures and traditions, in addition to continuing their development according to their needs and aspirations. (DAMBROS et al., 2020, p. 390). 
The indigenous population, as a whole, perceives this segregation, this erasure, which society insists on applying to indigenous peoples. Fernandes and Piovezana (2015) explain their feelings for concluding that: "[...] our schools, media and other cultural circuits are not fed by indigenous knowledge". Common sense, in this situation, is a trap that holds us in the illusions of the ecologically correct [...] "(FERNANDES; PIOVEZANA, 2015, p. 115)".

\section{Ethnodevelopment of the Kaingang Group of Oeste Paulista, in the Terra Indígena Vanuíre}

The way in which indigenous people Interact with the environment in which they live offers enriching information about their ecological and cultural relations with these groups.

Most indigenous groups in Brazil practice agriculture, and with the Kaingang group it is no different, this group has agriculture as one of the ways to promote its economy.

D'Angelis and Veiga (2009) explains that in traditionally cultivating the land, before the arrival of whites, they planted corn (some varieties), beans (a type of fava beans) and strawberries.

Among the plantations, cassava, corn, peanuts stand out, and among these foods cassava is reinforced as the main activity, because it is made from beijing Kaingang typical food (BORELLI, 1984; MELATTI, 1994).

After contact with the non-indigenous " [...] Indian Protection Service (SPI), early 20th century, they further diversified their agricultural production, incorporating, for example, beans [...]" (PINHEIRO, 1992, p. 62).

In addition to the aforementioned livelihoods, agriculture is also a way of organizing and producing other types of food such as vegetables, legumes and grains, avoiding the shortage of some supplies, according to Lima (2019).

A reservation is made for the planting of fruit trees, in most houses of the Kaingang group of the Terra Indígena Vanuíre, they have plantations of orchards, spices, vegetables, and some herbs such as mate and roots (PINHEIRO, 1992; LIMA, 2020).

Families usually carry out agroecological activities, for example, composting for better quality in their agricultural lands, economy activities are facilitated because it is intrinsically part of the indigenous nature to promote self-support activities, as reported by Luciano (2006).

The production of planting and cultivation is very important for the Kaingang indigenous peoples of the Terra Indígena Vanuíre located in the municipality of Arco-Íris in the interior of the state of São Paulo. 
The Pro-Indian Commission in the State of São Paulo (CPISP) reports some activities related to the economy of the Terra Indígena Vanuíre when quoting Herrero (2016, apud CPISP, 2020) where he concludes that:

\begin{abstract}
Despite the adverse historical conditions, Aldeia Vanuíre [...]. In the area there is cultivation of medicinal herbs and plants that generate seeds for handicrafts. They plant potatoes, manioc, corn, beans, peanuts and squash to sell and raise some cattle. They grow vegetables in their home gardens and count on the reinforcement of fruit from the orchards. There is also the creation of chickens and pigs. Retirements, the benefit of the Bolsa Família program and sporadic and seasonal work, poorly paid on farms in the region, add up to make up the families' income (HERRERO, 2016, p. 02).
\end{abstract}

One of the Kaingang group's customs is to organize themselves in such a way that all family members participate in agricultural and cultural activities, from the youngest to the oldest, in this way they already develop with the young people the dialogue of the memory of traditional culture.

Some of these activities are reported by D'Angelis and Veiga (2009), among such agricultural and cultural activities, in the past the Kaingang had four sources of food: gathering, hunting, fishing and agriculture. There is also the habit of chimarrão, which is multisecular among some Kaingang groups.

Gonçalves (2007) recognizes these agricultural and cultural activities, as he reports that:

Economically, the Kaingang organized themselves in an economy based on hunting, fishing, collecting and complementary agriculture, but today agriculture is the basic element of their economy, alongside families that depend exclusively on the sale of their handicrafts. (GONÇALVES, 2007, p. 06).

The Kaingang group of the Terra Indígena Vanuíre, as a way of promoting their economy, also make small trails in their territories with the visiting public presenting their culture, charging a symbolic value for the contribution of the indigenous economy.

These are moments of learning, in which the indigenous people show their respect for nature, transmit their knowledge along the trail, explaining the importance of each, trees, plants and herbs native to the region, and their experience with their elders.

D'Angelis and Veiga (2009) points out that in many places fruit trees are planted, such as butiá, papaya, among others, and in several places the planting of vegetables is also common. 
Another traditional Kaingang food made from purple corn is lamin, its form of preparation has also been passed down from generation to generation is consumed crushed into a paste, being rolled into a leaf similar to a banana leaf, and taken to roast (CAMPOS, 2014).

However, D'Angelis and Veiga warns that:

Most of the Kaingang lands are now used for commercial agriculture, mainly with soybeans, but also corn and beans. It was a terrible alternative introduced by FUNAI itself a few decades ago. Today there are serious problems in some areas because of this, with some leaders promoting land concentration. (D'AGELIS; VEIGA, 2009, p. 02).

Another strategy found by the Kaingang women of Dirce Jorge's family to strengthen culture and promote an income, was the creation of the Museum Worikg (Rising Sun), within the Terra Indígena Vanuíre (FUNAI, 2020a).

The museum was founded to store the belongings of Senhora Jandira, after her death, "[...] it is our fortress and it was our entrance to reach the way of museums [...]" (ISA, 2020, p. 01).

Gazoni (2014) provides more details, citing that:

The museum will serve interests related to the strengthening of cultural and social groups, generally with less representation and their collections. The search for a readjustment in the relationship with society involves the need for closer proximity to the museum with heritage that is not musealized. Initiatives to approach the museumwith the environment, they are looking for greater representativeness of their collections and democratization of the institution. (GAZONI, 2014, p.15).

As a Young man, Dirce Jorge indigenous Kaingang, already alerted his mother to the need to preserve culture, "[...] He Said that things had already changed, they were not as they were before, now there are non-Indian people in favor of the indigenous people [...] "(DOLCE, 2019, p. 01)"

This awakening to the preservation of culture is highlighted by Gazoni (2014) Who highlights the joint work carried out to maintain the museum:

The approximation between these universes allows the museum team to collect heritage senses directly with the 'owners' of the heritage, prioritizing the sense of man over the object, as in the new museum. (GAZONI, 2014, p.17). 
In the 1990s, Pinheiro (1999) highlights that, the sale of handicrafts was starting in the Indigenous Land, buyers were not Constant and producers were still few.

Currently, the handicrafts produced are one of the main sources of income and savings for the Kaingang group in the Terra Indígena Vanuíre, in addition to their economic importance, the artisanal activity represents the rescue of cultural aspects essential to the indigenous identity itself.

And even with difficulties in finding raw materials such as seeds for making their handicrafts in their territory, many of them are bought by the Kaingang group in shopping centers, as Melo (2020) reports, in their testimony in indigenous knowledge and practices.

\section{Final considerations}

In view of the research objectives presented here, to understand the historical and ethnographic content of the Kaingang group of the Terra Indígena Vanuíre, and how they promote their economy.

Studying for this bibliographic understanding the ethno-development concepts historicities of this group, the present article proves to be complex and instigating.

It can be seen that the traditional management, for the Kaingang group in the Terra Indígena Vanuíre, makes it possible in a balanced way to remove substrates from nature to collaborate with their economy, it is important to emphasize for our understanding that, for indigenous peoples, it is inseparable to relationship between sustainability and survival.

Even facing problems such as soil wear and tear, Kaingang indigenous families look to agriculture for their source of income, with corn plantations, cassava and others discussed in this study.

Another source of income comes from handicrafts. It was observed that even the Kaingang group having difficulties in finding raw materials such as some seeds for making their handicrafts, being obliged to look for these seeds in shopping centers, in order to be able to exercise their activity, even so they fight for the preservation of culture and with it seeking their source of economy.

Handicraft for indigenous peoples is an element that runs through all its spheres, part of their knowledge, culture and history is there, in that made piece, available to all people.

It was also observed as a strategy of economy and strengthening of culture, the creation of the Worikg museum (Sol Nascente), within the Terra Indígena Vanuíre, by the Kaingang women of the family of Dirce Jorge. 
Crafts are for sale outside the Museum, and the public can also choose to take a walk on an ecological trail.

\section{References}

ANDRIOLLI, I. N. CANDIDATE J.E.P. Kaingang and food production. In: MERCOSUR. Available in: http://fidamercosur.org/claeh/experiencias/experiencias-en-laregi\%C3\%B3n/939-o-kaingang-ea-produ\%C3\%A7\%C3\%A3o-dealimentos\#: :text = The\% 20\% C3\% ADndios\% 20Kaingang\% 20s\% C3\% A30\% 20considered, ind\% C3\% ADgenas\% 20more\% 20popular\% 20no\% 20Brazil. Accessed on: 23 sep. 2020.

D'ANGELIS, W. R.; VEIGA, J. Food for the Kaingang, yesterday and today. Available in:http://www.portalkaingang.org/Alimentacao Kaingang.pdf. Accessed on: 06 set. 2020.

BAPTISTA, J. Hunger in missional villages: historical dynamics amidst the debate on subsistence between Jesuits and indigenous people. Byblos. Rio Grande, vol. 22, m. 2. P. 27-38, 2008. Available at:https://periodicos.furg.br/biblos/article/view/959. Accessed on: 05 sep. 2020.

BORELLI, S. H. S. The Kaingang in the state of São Paulo: historical constants and deliberate violence. In: BORELLI, SHS et al. (orgs.). Indians in the State of São Paulo: Resistance and Transfiguration. São Paulo: Yankatu, 1984. 152p.

BUSSOLI, J. Kaingang Territoriality of the Pó Mág Community in Tabai, southern portion of the Taquari-Antas Hydrographic Basin. 2018. Dissertation (Master) Environment and Development Course, University of Vale do Taquari - Univates, Lajeado, 20 Dec. 2018. Available at:https://hdl.handle.net/10737/2470. Accessed on: 29 sep. 2020.

CAMPOS, J. S. FISHING LOCA KAINGANG AND KRENAK: Terra Indígena Vanuíre, India Vanuíre State School Project. Production Historical and Pedagogical Museum India Vanuíre. Tupã, 2014. 01 DVD (60 min), son., Color.

SÃO PAULO PRO-INDIAN COMMISSION. Kaingang. Vanuíre village. 2020. Available at: https://cpisp.org.br/indios-em-sao-paulo/povos-indigenas/kaingang. Accessed on: 18 nov. 2020.

CURY, M. X. Memórias do Território and Resistencia Kaingang: in the west of São Paulo. In: CARNEIRO, MLT; ROSSI, MS (org). Indians in Brazil life, culture and death. 1. ed. São Paulo: Intermeios, 2019. 299p.

CURY, M. X.; FABBRI, A. Memories of the Territory and Resistance Kaingang: the contribution and experience of the India Vanuíre Museum. In: CARNEIRO, MLT; ROSSI, MS (org). Indians in Brazil life, culture and death. 1. ed. São Paulo: Intermeios, 2019. 299p. 
DAMBROS, B. et al. Recognition of the rights of indigenous peoples: A study in the light of the Brazilian Constitutions. Legal Journal (0103-3506). Jan-Mar. 2020 vol.1, edition 58, pp. 573-604. 32p. Available in:https://web.a.ebscohost.com/abstract?direct=true\&profile=ehost\&scope=site \&authtype $=$ crawler\&jrnl $=01033506 \& A N=142689314 \& \mathrm{~h}=\mathrm{AKJ} 1 \mathrm{adrHTqdfNbxN5K}$ mcWGO8812VZdMHkvTU6Zw3nlRXSY01G\%2fmeVRTAF8mX2PV1Hno43P6VMQ\%2 b3xAlhwdoK3A\%3d\%3d\&crl=c\&resultNs=AdminWebAuth\&resultLocal=ErrCrlNo tAuth\&crlhashurl=login.aspx\%3fdirect\% 3dtrue\% 26profile\% 3dehost\% 26scope\% 3dsite\% 26authtype\% 3dcrawler\% 26jrnl\% 3d01033506\% 26AN\% 3d142689314. Accessed on September 262020

D'ANGELIS, W. R.; VEIGA, J. Food for the Kaingang, yesterday and today. 2009. Available at:http://www.portalkaingang.org/Alimentacao Kaingang.pdf. Accessed on: 06 set. 2020.

DOLCE, J. Dirce Lipu Pereira: the Kaingang shaman who returned to sing. Keeping an eye on the ruralist. Available in:https://deolhonosruralistas.com.br/2019/03/18/dirce-lipu-pereira-a-paje-quevoltou-a-cantar/. Accessed on: 22 out. 2020.

FERNANDES, R. C.; PIOVEZANA, L. Kaingang perspectives on land and environmental rights in southern Brazil. Environment. soc., São Paulo, Vol. 18, n. 2, p. 111-128, June 2015. Available at <http://www.scielo.br/scielo. php? script $=$ sci_arttext\&pid $=S 1414-753 \times 2015000200008 \& \operatorname{lng}=$ en $\& \mathrm{nrm}=$ iso $>$. Accessed on November 16, 2020. http://dx.doi.org/10.1590/18094422ASOCEx07V1822015en.

NATIONAL FOUNDATION OF INDIO. Handicrafts promote the maintenance of Kaingang culture in the South of the country. Available in:http://www.funai.gov.br/index.php/comunicacao/noticias/5043-artesanatopromove-manutencao-da-cultura-kaingang-no-sul-do-pais. . Accessed on: 21 sep. 2020.

NATIONAL FOUNDATION OF INDIO. Terra Indígena Vanuíre. Available in:https://terrasindigenas.org.br/pt-br/terras-indigenas/3896\#direitos. Accessed on: 16 jan. 2020a.

NATIONAL FOUNDATION OF INDIO. Terra Indígena Araribá. Available in:https://terrasindigenas.org.br/pt-br/terras-indigenas/3599. Accessed on: 22 abr. 2020b.

NATIONAL FOUNDATION OF INDIO. Terra Indígena Icatu. Available in:https://terrasindigenas.org.br/pt-br/terras-indigenas/3684. Accessed on: 22 abr. 2020c.

NATIONAL FOUNDATION OF INDIO. Indigenous policy. Available in:http://www.funai.gov.br/index.php/nossas-acoes/politica-indigenista. Accessed on: 14 nov. $2020 \mathrm{~d}$.

GAZONI, P. M. The contemporary in the museum: the Kaingang and the India Vanuíre de Tupã Historical and Educational Museum - São Paulo. 2014. Dissertation (Master in Museology) - Museum of Archeology and Ethnology, University of São Paulo. SP. 2014. Available at:https://tese.usp.br/tese/disponiveis/103/103131/tde13022015-102749/publico/PatriciaMacielREVISADA.pdfAccessed on: 19 nov. 2020.

GONÇALVES, S.A. Appearance at Kaingang. 2007. Dissertation (Master in Linguistics at the Institute of Language Studies) - State University of Campinas, Institute of Language Studies, Campinas, SP. Available in:http://www.repositorio.unicamp.br/handle/REPOSIP/268995. Accessed on: 14 nov. 2020.

INSTITUTO SOCIO AMBIENTAL. Indigenous Lands. Available in:https://terrasindigenas.org.br/pt-br/noticia/197662. Accessed on: 06 set. 2020c. 
LIMA, A. T. Brazilian Indigenous Public Policy: Analysis of transformations from the case study of Aldeia Indígena Vanuíre (ARCO-IRIS / SP). 2019. Dissertation (Master in Agribusiness and Development) - Universidade Estadual Paulista de Tupã, Tupã, 2019. Available at:https://repositorio.unesp.br/bitstream/handle/11449/181462/lima at me tupa. pdf? sequence=3. Accessed on: 01 apr. 2020.

LUCIANO, G. S. The Brazilian Indian: what you need to know about indigenous peoples in Brazil today. Brasília: Ministry of Education, Secretariat for Continuing Education, Literacy and Diversity; LACED / National Museum, 2006. 233p. E-book. Available in: http://www.educadores.diaadia.pr.gov.br/arquivos/File/cfc/livrocolecao.pdf. Accessed on: 19 sep. 2019.

MELATTI, J. C. Indians of Brazil. São Paulo: Hucitec. 8. ed. 1994. 220p.

MONTEIRO, J. Life and death of the Indian: São Paulo Colonial. In: BORELLI, S. H. S. et al. (orgs.). Indians in the State of São Paulo: Resistance and Transfiguration. São Paulo: Yankatu, 1984. 152p.

MORAES, N. R. et al. The concept of territory within traditional Brazilian communities. Observatório Magazine, Palmas, vol. 2, n. 2, p. 442-455, out. 2016. Available at:https://sistemas.uft.edu.br/periodicos/index.php/observatorio/article/view/286 9/9042. Accessed on: 19 sep. 2020.

MUSEU HISTÓRICO E PEDAGÓGICO INDIA VANUIRE. The Kaingang. Available in:https://www.museuindiavanuire.org.br/india-vanuire/os-kaingang. Accessed on: 11 sep. 2020.

PINHEIRO, NS OS NÔMADES: Ethnohistory Kaingang and its context São Paulo, 18501912. 1992. Dissertation (Master of Science and Letters) - Universidade Estadual Paulista de Assis, Assis, 1992. Available at:https://repositorio.unesp.br/bitstream/handle/11449/145521/000022454.pdf?s equence $=1$. Accessed on: 01 apr. 2020.

PINHEIRO, NSVanuíre: Conquest, Colonization and Indigenism: West Paulista, 19121967. Tese (Doctoral Thesis in History) - Faculty of Sciences and Letters of Assis Universidade Estadual Paulista, Assis, 1999. Available at:https://repositorio.unesp.br/bitstream/handle/11449/145478/000143349.pdf?s equence $=1$. Accessed on: 15 nov. 2020.

RIBEIRO, D. Indians and civilization. São Paulo: Book Circle. 1988. 460p.

RIBEIRO, B. The Indian in the history of Brazil. 12. ed. São Paulo: Global. 2009. 143p.

RODRIGUES, AR; NISHIKAWA, L. D. The socio-environmental condition in the "india vanuíre" indigenous area, municipality of rainbow, and the possibilities for agroecological adaptation and forest recovery. In: Alta Paulista Environmental Forum. 3., 2007, Araporã. Annals. [...]. CEIMAM / UNESP / Fundação Araporã. Available in:http://fundacaoarapora.org.br/artigospdf/area indigena.pdf. Accessed on: 05 sep. 2020.

RODRIGUES, AR; NISHIKAWA, L. D. Understanding the Kaingang territory in Western São Paulo from material culture: interpretive possibilities in archaeological analysis. São Paulo: Revista Museu Arqueologia Etnologia, n. 27, p. 44-54, 2016. Available at: www.revistas.usp.br. Accessed on: 15 jul. 2020.

SILVA, J. B. S.; LAROQUE, LFS The Kaingang history of the Linha Glória indigenous land, Estrela, Rio Grande do Sul / Brazil: meanings of their (re) territoriality. Soc. Nat., Uberlândia, v. 24, n. 3, p. 435-447, dec. 2012. Available from http://www.scielo.br/scielo.php?script=sci_arttext\&pid=S198245132012000300005\&lng=en\&nrm=iso. Accessed on: 18 nov. 2020.https://doi.org/10.1590/S1982-45132012000300005.

VEIGA, J. Fundamental aspects of Kaingang culture. Campinas: Curt Nimuendajú, 2006. 


\section{Crevisto Observatório}

\section{RESUMO:}

O presente artigo tem como objetivo descrever o conteúdo histórico e etnográfico do grupo Kaingang do Oeste Paulista, na Terra Indígena Vanuíre, e como promovem sua economia. Os Kaingang são povos pertencentes ao tronco linguístico Macro-Jê, e família Jê, é considerado um dos maiores grupos indígenas do ponto de vista populacional. A metodologia adotada para o desenvolvimento deste artigo parte da tipologia bibliográfica e descritiva, tendo como técnica a pesquisa documental. Espera-se obter, com deste artigo, um conjunto sistematizado de informações, que ao alcançar o objetivo do trabalho, possa contribuir para o melhor entendimento sobre a economia do grupo Kaingang do Oeste Paulista, na Terra Indígena Vanuíre.

PALAVRAS-CHAVE: Etnodesenvolvimento; Kaingang; Terra Indígena Vanuíre.

\section{RESUMEN:}

Este artículo tiene como objetivo describir el contenido histórico y etnográfico del grupo Kaingang del Oeste Paulista, en la Tierra Indígena Vanuíre, y cómo promueven su economía. Los Kaingang son pueblos pertenecientes al grupo lingüístico Macro-Jê, y la familia Jê es considerada uno de los grupos indígenas más grandes desde el punto de vista poblacional. La metodología adoptada para el desarrollo de este artículo se basa en la tipología bibliográfica y descriptiva, utilizando como técnica la investigación documental. Se espera obtener, con este artículo, un conjunto sistemático de información que, al alcanzar el objetivo del trabajo, puede contribuir a una mejor comprensión de la economía del grupo Kaingang en el Oeste de São Paulo, en la Tierra Indígena Vanuíre.

PALABRAS CLAVE: Etnodesarrollo; Kaingang; Terra Indígena Vanuíre. 